\title{
Democracy / Participation-Based Corporate Social Responsibility Management Improves Public Welfare in Indonesia
}

\author{
Suwandi $^{1}$, Roberto Akyuwen ${ }^{2}$, Agnes Dwita Susilawati ${ }^{3}$ \\ 1,2,3 University of Pancasakti Tegal
}

\begin{abstract}
:
CSR is a responsibility that must be implemented by every company, where the company's responsibility is not only on the financial condition. But corporate responsibility (CSR) is also related to all stakeholders included their family employees. The existence of a company can have two impacts, namely positive and negative, therefore the company needs to prevent negative impacts that may arise and can interfere with the company's operations and community activities. This, CSR is very necessary to be implemented in every company. This research uses qualitative research and uses a deductive approach. The results of this study indicate that the implementation of CSR is indispensable in a company, the variable of participation democracy takes part in the establishment of the company and the level of welfare of the Indonesian people is one of the impacts of the success of a company in promoting the concept of CSR.
\end{abstract}

Keywords: Corporate Social Responsibility, responsibility, community

\section{Introduction}

Corporate Social Responsibility is a theory that explains the importance of a company in implementing its operational activities to always build harmonious relationships and make a positive contribution to society and the environment [1]. The role of morals is very important and influential in all social aspects including attitude, economic aspects including business and companies and even cultural aspects. This, CSR has an active role in a company related to responsibility towards stakeholders, especially employees and communities around the company's work area. UU no. 40 of 2007 Article 66 paragraph 2 part $\mathrm{c}$ describes the responsibilities of a company in which it is related to financial responsibility, corporate activities and responsibility for social and environmental activity reports (Law Number 40 of 2007 Article 66 Paragraph 2, nd).

This makes corporate responsibility a necessity both in economic and social terms. Because when a company is established and gets permission from the community, there will automatically be a profit chasing within the regulatory boundaries that have been determined by the community [3]. Companies also have to take responsibility for the ecological costs of society for their actions [4].

Social responsibility that is carried out will give birth to the welfare of the community, government and all elements involved in a country. Meanwhile, natural resources are the basic capital for the welfare of the country [5]. Therefore, the abundant natural resources in Indonesia must really be utilized, even if it is processed properly and environmentally friendly by companies in Indonesia, especially companies that produce waste [6].

Investors give appreciation to companies that apply the concept of CSR, because if the company does not implement the CSR concept, it could be that the company is unable to maintain its business sustainability so that investors are not interested in investing in the company [7].

This is because CSR is very important because this CSR concept provides some positive energy, including fulfilling regulations, laws and regulations, as a corporate social investment to get a positive image, CSR is also included in the business strategy section and the risk management section of the company to reduce and avoid social conflicts [8].

Various kinds of factors cause why social responsibility becomes so important in the scope of the organization, including:

1. The flow of globalization, which provides an illustration of the disappearance of the boundary lines between various regions of 
the world, thus presenting universality [9]. Thus, it is possible for multinational companies to develop anywhere as a globalization link.

2. Consumers and investors as the primary public profit organizations need a description of the organization's responsibility for social and environmental issues [10]

3. As part of organizational ethics, organizational responsibility is needed to be able to manage the organization well (better known as good corporate governance).

4. People in some countries consider that the organization has met ethical standards of organization, when the organization cares about the environment and social problems [11].

5. Social responsibility can at least reduce crises that have the potential to occur in the organization [12].

6. Social responsibility is considered to increase the reputation of the organization [13].

There are many benefits that can be obtained from the concept of CSR, including: implementing CSR can reduce the risk of inappropriate treatment received by the company, as a protector and help the company minimize the adverse effects caused by the crisis.[14].

\section{Literature Review}

\section{Corporate Social Responsibility}

Corporate Social Responsibility theory describes the importance of accountability in a company [15] There is a broad definition from the World Business Council for Sustainable Development (WBCSD), that CSR is a company agreement to act ethically and have a positive impact on the economic development of the company, employees, stakeholders and the wider community [16].

The commitment implemented by CSR is closely related to business ethics and the social dimensions of business activities [17]. This means that the implementation of CSR in each country has a different context, because conditions in developed and developing countries are also different in terms of the economy, social and even the culture of the citizens of a country [18]. According to Suwandi et al. (2013) it is also stated that the dimensions of CSR include economic, social, legal, ethical, environmental, and others.

The CSR movement is applied in developed countries because of the awareness and voluntary encouragement [20]. Kotler said that CSR is implemented because it is not because it has been mandated by law, morals or even ethics, but CSR is carried out because it is more inclined because of a voluntary commitment by corporations in selecting and implementing CSR practices [21].

There are two types of CSR concepts, namely CSR in a broad and narrow sense [22]. Csr in a broad sense is long-term economic activity, where economic activity is not only about social responsibility but also about corporate accountability to the community and the international community [23] While CSR in a narrow sense has many meanings put forward by experts, one of which is CSR according to Kotler and Nance, which is a corporate commitment to the welfare of society through policies in business and distribution of corporate resources [24].

There are three basic understandings of CSR, including: first, a role that is voluntary, in which the company is tasked with helping to overcome social and environmental problems. Second, the company has the duty to set aside a portion of its profit for generosity, which aims to empower society and improve when there is environmental damage. Third, CSR is a company obligation to pay attention to the environment and people who are experiencing a crisis [25].

\section{Participatory Democracy}

The democratic approach appears on the principle of equality, this means that every citizen in a country that applies democracy has the same rights regardless of culture, wealth and descent [26]. Because the real sovereignty is held by the people which then becomes a source of legitimacy and legality of state power (E-Journal.Uajy.Ac.Id, nd).

Bagir Manan expressed his opinion that community participation can be carried out in various ways, one of which is including the community involved in a project, either a company or a regional law [28].

The theory of participatory democracy assumes that the existence of a company can run well if participatory democracy is considered, in the sense that the company has responsibilities that should be carried out when it is related to business activities, both people who are in the company and the place where the company conducts business activities [29]. In community life, CSR can develop itself and its business so that the goal of achieving prosperity is achieved [30]. This is intended for the implementation of CSR which must be effective and targeted. 


\section{Level of Welfare of Indonesian Society}

In general, CSR is interpreted as a way in which the name of the company strives to achieve a balance between economic, environmental and social objectives in order to maintain a balance of relationships between entrepreneurs and the surrounding community, because according to the ethical approach of an economic institution called business, it cannot be separated from its existence. Public [31] This is due to the fact that business as a subsystem has lived or existed in society, therefore it cannot be separated from its existence from society or its social relationships [32].

The level of welfare of the Indonesian people can be measured by indicators of social and economic aspects because there are many problems that arise due to inadequate needs. According to Akwuyen \& Suwandi (2017) the indicators used to identify the level of welfare vary widely. For example, a person can be categorized as poor if they have low income, have poor health, have low education, consume foods with low nutrition, live in a house that is not suitable for habitation, and so on.

To improve community welfare is a balance in the social responsibility system, it can be carried out according to the role and function of each party, the process and all missions carried out are carried out in a balanced way for all parties who must be given a contribution to the rights as a community and an equivalent obligation as an actor effort [34].

The implementation of corporate social responsibility has had a lot of influence on the surrounding community. Helping underprivileged people to meet their needs is one of the goals of CSR management for community welfare [35].

The implementation of the CSR model program is a form of the quality of the company's environmental life that has the ability of humans as individual members of society to have a role in responding to existing social conditions and can be enjoyed and utilized, utilize and maintain the environment [36] The results show that the implementation of the company's CSR program which involves community participation, useful programs, programs that can develop knowledge and programs that can increase cooperation among community members will be able to shape or influence the strengthening of community social capital [37].

Based on the existing point of view, it shows that what the company has done has described the success in implementing the company's CSR [38].
This can be seen from the various indicators of activity programs that have been implemented periodically and continuously. Compensation for the poor and community social development in order to maintain public order are examples of several corporate CSR programs that can be felt positively by the community [39].

The level of welfare of the Indonesian people can be measured by indicators of social and economic aspects because there are many problems that arise due to inadequate needs (Citra Kunia putri and trisna insan Noor, 2013). The welfare of the Indonesian people also depends on companies, especially companies that are located around large crowds of residents [41].

In implementative terms, the development of CSR in Indonesia still really needs attention from all parties, including the government, companies and the wider community. Because after it is indicated that some companies in Indonesia do not apply the concept of CSR in their company activities [42].

The results showed that the company's CSR program which is carried out by involving community participation, useful programs, programs that can develop knowledge and programs that can increase cooperation among community members will be able to strengthen the existing social capital in the community, including trust, norms norms (norms), and networks (network) [43].

Pene results This litian supports this opinion Aprianthiny (2015) that CSR and social capital have a two-way relationship that is quality and mutually influencing, and the results of the research state that CSR implementation in society can be categorized as social capital because one of the company's successes is business sustainability. CSR is one of the factors of business sustainability by increasing trust in external parties, especially in the community environment because with the implementation of CSR, companies are required to be more responsible for the environment and the community around the company.

\section{Research methods}

This research is descriptive with qualitative research type. The type of approach used is the deductive approach, which is an approach that uses logical reasoning to draw conclusions from several assumptions.

\section{Results and Discussion}

Social responsibility or CSR is a company or business world commitment to the impact arising 
from its operational activities. In addition to profitgenerating activities, companies need to carry out other activities that involve the surrounding community, even though it is a service company. These activities, among others, are related to social activities in the community, customer products and services, employment, the environment, and other activities that involve the community around the company. Community participation must be well understood so that the goal of empowering the community through participatory development can be achieved.

In general, CSR is interpreted as a way in which the name of the company strives to achieve a balance between economic, environmental and social objectives in order to maintain a balanced relationship between entrepreneurs and the surrounding community, because according to the ethical approach of an economic institution called business, it cannot be separated from its existence. Public. This is because the subsystem of business has lived or existed in society, therefore it cannot be separated from its existence from society or its social relationships.

If CSR is implemented properly, the objectives of socio-economic justice, wealth distribution will be evenly distributed and it is an integral part of the Islamic moral philosophy which is based on its commitment to a sense of brotherhood and humanity.

In order to improve community welfare, it is a balance in the social responsibility system, it can be carried out according to the roles and functions of each party, the process and all missions carried out are carried out in a balanced manner for all parties who must be given a contribution to the rights as a community and an equivalent obligation as an actor effort.

The implementation of corporate social responsibility has had a lot of influence on the surrounding community. Helping underprivileged people to meet their needs is one of the goals of CSR management for community welfare.

The implementation of the CSR model program is a form of the quality of the company's environmental life that has the ability of humans as individual members of society to have a role in responding to existing social conditions and can be enjoyed and utilized, utilize and maintain the environment. The results showed that the implementation of the company's CSR program which involves community participation, useful programs, programs that can develop knowledge and programs that can increase cooperation among community members will be able to shape or influence the strengthening of community social capital.

Based on the existing point of view, it shows that what the company has done has described the success in implementing the company's CSR. This can be seen from the various indicators of activity programs that have been implemented periodically and continuously. Compensation for the poor and community social development in order to maintain public order are examples of several corporate CSR programs that can be felt positively by the community.

In the theory of participation (Uphoff, 1979) that participation in decision making is manifested by community participation in meetings. The decisionmaking stage referred to here is the planning and implementation of a program.

The development of Corporate Social Responsibility (CSR) for the Indonesian context can be seen from two different perspectives, this was stated by Solihin (2008). First, the implementation of CSR is indeed a voluntary business practice that comes from company initiatives. Second, the implementation of CSR is no longer a voluntary business practice, but its implementation is regulated by a mandatory law. Conceptually CSR in Indonesia still has to be divided between CSR implementation by large companies and CSR implementation by small and medium companies. So far, there is a misconception that CSR is only intended for large companies, even though it is not only large companies that can have a negative impact. CSR carried out by small and medium companies in Indonesia still revolves around opening jobs for the surrounding community and giving charity to the surrounding community.

\section{Conclusions}

Based on the discussion above, it can be formulated in a conclusion including:

1. CSR is something that is achieved by companies or business actors in contributing to sustainable community or social involvement in achieving efforts to improve the quality or welfare of the company and society.

2. The application of CSR is very necessary in a company.

3. Participation democracy variable took part in the establishment of the company.

4. The level of welfare of the Indonesian people is one of the impacts of the success of a company in promoting the concept of CSR. 


\section{Reference}

1. R. A. Sari, "PENGARUH KARAKTERISTIK PERUSAHAAN TERHADAP CORPORATE SOCIAL RESPONSIBILITY DISCLOSURE PADA PERUSAHAAN MANUFAKTUR YANG TERDAFTAR DI BURSA EFEK INDONESIA," Nominal, Barom. Ris. Akunt. dan Manaj., 2012, doi: 10.21831/nominal.v1i2.1002.

2. "Undang-undang Nomor 40 Tahun 2007 Pasal 66 ayat 2."

3. N. Margolang, "PEMBERDAYAAN MASYARAKAT," Dedik. J. Community Engag., 2018, doi: 10.31227/osf.io/weu8z.

4. A. Puspaningsih and I. P. Rahmawati, "PENGARUH CORPORATE SOCIAL RESPONSIBILITY TERHADAP NILAI PERUSAHAAN DENGAN PROSENTASE KEPEMILIKAN MANAJEMEN SEBAGAI VARIABEL MODERATING," J. Apl. Bisnis, 2012, doi: 10.20885/jabis.vol13.iss9.art1.

5. Setiyawan, "Sumber Daya Alam," J. Chem. Inf. Model., 2013.

6. R. Pillai and H. A. N. Al-Malkawi, "On the relationship between corporate governance and firm performance: Evidence from GCC countries," Res. Int. Bus. Financ., 2018, doi: 10.1016/j.ribaf.2017.07.110.

7. M. Ibrahim, E. Z. Solikahan, and A. Widyatama, "Karakteristik Perusahaan, Luas Pengungkapan Corporate Social Responsibility, dan Nilai Perusahaan," J. Akunt. Multiparadigma, 2015, doi: 10.18202/jamal.2015.04.6008.

8. G. B. Nayenggita, S. T. Raharjo, and R. Resnawaty, "PRAKTIK CORPORATE SOCIAL RESPONSIBILITY (CSR) DI INDONESIA," FocUS J. Pekerj. Sos., 2019, doi: 10.24198/focus.v2i1.23119.

9. R. Mustapha and R. Husin, "Sumber Manusia Dalam Era Globalisasi Dan K-Ekonomi," J. Teknol., 2002.

10. Z. Wang and J. Sarkis, "Corporate social responsibility governance, outcomes, and financial performance," J. Clean. Prod., 2017, doi: 10.1016/j.jclepro.2017.06.142.

11. R. Rifayanti, A. Saputri, A. K. Arake, and W. Astuti, "Peran Role Model Dalam Membentuk Perilaku Pro-Lingkungan," Psikostudia J. Psikol., 2019, doi: 10.30872/psikostudia.v7i2.2402.

12. A. D. Maraya and R. Yendrawati, "Pengaruh corporate governance dan corporate social responsibility disclosure terhadap tax avoidance: studi empiris pada perusahaan tambang dan CPO," J. Akunt. Audit. Indones., 2016, doi: 10.20885/jaai.vol20.iss2.art7.

13. K. Haynes, A. Murray, and J. Dillard, Corporate social responsibility. 2012.

14. A. Khan, M. B. Muttakin, and J. Siddiqui, "Corporate Governance and Corporate Social Responsibility Disclosures: Evidence from an Emerging Economy," J. Bus. Ethics, 2013, doi: 10.1007/s10551-012-1336-0.

15. S. Sumanti, "CSR Pemberdayaan Masyarakat," J. Sos. Soedirman, 2020.

16. S. Rokhlinasari, "Teori -Teori dalam Pengungkapan Informasi Corporate Social Responbility Perbankan," BMC Public Health, 2017.

17. M. Romi, "CORPORATE SOCIAL RESPONSIBILITY (CSR):Tinjauan Teori dan Praktek di Indonesia," J. Apl. Bisnis, 2012.

18. M. Budiarti and S. T. Raharjo, "CORPORATE SOCIAL RESPONSIBILITY (CSR) DARI SUDUT PANDANG PERUSAHAAN," Share Soc. Work J., 2014, doi: 10.24198/share.v4i1.13045.

19. Suwandi, Y. T. Keban, and E. Martono, "PRAKTIK TANGGUNG JAWAB SOSIAL PERUSAHAAN PT. BAKRIE SUMATRA PLANTATIONS(TBK.) UNIT JAMBI," J. Kawistara, 2013, doi: 10.22146/kawistara.3982.

20. Lindrawati, N. Felicia, and J. T. Budianto, "Pengaruh Corporate Social Responsibility terhadap Kinerja Keuangan perusahaan yang terdaftar Sebagai100 Best Corporate Citizens oleh KLD Research \& Analytics," Maj. Ekon., 2008.

21. B. Cheng, I. Ioannou, and G. Serafeim, "Corporate social responsibility and access to finance," Strateg. Manag. J., 2014, doi: 10.1002/smj.2131.

22. A. P. Nasution, "PENTINGKAH COORPORATE SOCIAL RESPONSIBILITY ?," Opini, 2016.

23. H. Liang and L. Renneboog, "On the Foundations of Corporate Social Responsibility," J. Finance, 2017, doi: 10.1111/jofi.12487.

24. V. Stanciu and F. P. Bran, "Why corporate social responsibility?," Qual. - Access to Success, 2016, doi: 10.7312/ande15922-003.

25. K. Kross, "Corporate social responsibility (CSR)," in Profession and Purpose: A Resource Guide for MBA Careers in 
Sustainability, 2013.

26. S. Lubis, "Partisipasi Masyarakat dalam Kebijakan Publik," Demokrasi, 2017.

27. "E-journal.uajy.ac.id."

28. Khairudin and L. Bruno, "Partisipasi Masyarakat," Psikol. Perkemb., 2019.

29. M. A. Camilleri, "Corporate Social Responsibility: Theoretical Underpinnings and Conceptual Developments," 2017.

30. Suwandi, Mengenal Corporate Social Responbility (CSR) Teori dan Praktik. Yogyakarta: Sekolah Pascasarjana Universitas Gadjah Mada, 2017.

31. K. Kross and K. Kross, "Corporate social responsibility (CSR)," in Profession and Purpose, 2019.

32. S. Du, C. B. Bhattacharya, and S. Sen, "Maximizing business returns to corporate social responsibility (CSR): The role of CSR communication," Int. J. Manag. Rev., 2010, doi: 10.1111/j.1468-2370.2009.00276.x.

33. R. Akwuyen and Suwandi, Keuangan Mikro Untuk Penanggulangan Kemiskinan. Yogyakarta: Sekolah Pascasarjana Universitas Gadjah Mada, 2017.

34. H. Aguinis and A. Glavas, "What We Know and Don't Know About Corporate Social Responsibility: A Review and Research Agenda," J. Manage., 2012, doi: 10.1177/0149206311436079.

35. C. Flammer, "Does corporate social responsibility lead to superior financial performance? A regression discontinuity approach," Manage. Sci., 2015, doi: 10.1287/mnsc.2014.2038.

36. S. Brammer, G. Jackson, and D. Matten, "Corporate social responsibility and institutional theory: New perspectives on private governance," Socio-Economic Rev., 2012, doi: 10.1093/ser/mwr030.

37. S. Sen and C. B. Bhattacharya, "Does doing good always lead to doing better? Consumer reactions to corporate social responsibility," J. Mark. Res., 2001, doi: 10.1509/jmkr.38.2.225.18838.

38. A. R. Pranoto and D. Yusuf, "Program CSR Berbasis Pemberdayaan Masyarakat Menuju Kemandirian Ekonomi Pasca Tambang di Desa Sarij aya," J. IImu Sos. dan Ilmu Polit., 2016, doi: 10.22146/jsp.13094.

39. L. Nirmalasari and S. Ulum, "Corporate Social Responsibility: Respon Publik dan dampaknya Pada Corporate Image," Study Account. Res., 2014.

40. 2011 Citra Kunia putri dan trisna insan Noor, "Kesejahteraan Masyarakat," Anal. pendapatan dan tingkat Kesejaht. rumah tangga petani, 2013.

41. I. K. Oka et al., "Pengaruh Pertumbuhan Ekonomi Dan Disparitas Pendapatan Antardaerah Terhadap Kesejahteraan Masyarakat Provinsi Bali," E-Jurnal Ekon. Pembang. Univ. Udaya, 2015.

42. A. Mapisangka, "Implementasi CSR terhadap Kesejahteraan Hidup Masyarakat," JESP Vol. 1, No. 1, 2009.

43. S. P. Saeidi, S. Sofian, P. Saeidi, S. P. Saeidi, and S. A. Saaeidi, "How does corporate social responsibility contribute to firm financial performance? The mediating role of competitive advantage, reputation, and customer satisfaction," J. Bus. Res., 2015, doi: 10.1016/j.jbusres.2014.06.024.

44. K. D. Aprianthiny, "Implementasi Corporate Social Responsibility (CSR) Sebagai Modal Sosial Pada PT Tirta Mumbul Jaya Abadi, Singaraja Bali," J. Jur. Pendidik. Ekon., 2015. 